\title{
HYDROPOWER GENERATION ON THE NYSA KLODZKA RIVER
}

\author{
HYDROENERGETYCZNE WYKORZYSTANIE \\ RZEKI NYSA KŁODZKA
}

\begin{abstract}
Adopted in 2009, the Directive of the European Parliament and of the Council on the promotion of the use of energy from renewable sources sets out the rules for how Poland is to achieve the $15 \%$ target of total primary energy from renewables by 2020 . However, there are fears that the goals set out in this Directive may not be met. The share of Renewable Energy Sources (RES) in national energy consumption (150 TWh) is estimated at 8.6 TWh in 2009 and 12 TWh in 2011 (5.7 and 8\% respectively). The level of RES in Poland until 2005 was approx. 7.2\%. The analysis of RES technologies currently in use in Poland shows that in terms of the share in the total capacity, the 750 hydro-electric power plants which are currently in operation (with the overall capacity of almost $0.95 \mathrm{GW}$ ) are second only to wind power stations $(2 \mathrm{GW})$. The authors have studied the Nysa Klodzka River in terms of possible locations for hydro-electric facilities. Eight locations have been identified where power plants might be constructed with installed capacities ranging from 319 to $1717 \mathrm{~kW}$. The expected total annual electric power generation of these locations would stand at approx. $37.5 \mathrm{GWh}$.
\end{abstract}

Keywords: river, renewable sources of energy, hydropower engineering, power generation

\section{Introduction}

The past several years have witnessed a growing interest in energy in the context of environmental protection and climate change [1-7]. The best proof of it is to be seen in the recent EU climate and energy summits. In March 2007, at the energy summit in Brussels, the EU leaders decided that Europe would commit to drastically increase the share of renewable energy sources in its overall energy balance. The key disagreement was over a proposal that all member states should commit to a target of $20 \%$ of renewables in total energy supply by 2020 [8]. As the presiding member state Germany called for adopting a binding agreement. The initiative was supported by the UK, Italy and most of the Scandinavian countries. Berlin emphasised that only then could the European Union

\footnotetext{
${ }^{1}$ Institute of Environmental Engineering, Faculty of Environmental Engineering and Geodesy, Wrocław University of Environmental and Life Sciences, pl. Grunwaldzki 24, 50-363 Wrocław, Poland, phone +48713205519, fax +48713205579

${ }^{2}$ Department of Land Protection, Faculty of Natural and Technical Sciences, Opole University, ul. Oleska 22, 45-052 Opole, Poland, phone +48 7740160 27, fax +48 7740160 30, email: wiatkowski@uni.opole.pl

*Corresponding author: robert.kasperek@up.wroc.pl
} 
realistically consider significant reduction of its $\mathrm{CO}_{2}$ emissions - namely by $20 \%$ or even $30 \%$ by 2020 . The main point of the March 2008 summit, in turn, was to commit to adopting a climate change legislative package until spring 2009 at the latest. This package was to require that by 2020 the level of renewable energy in the EU would rise from $8.5 \%$ to $20 \%$ and that the carbon dioxide emission would be cut by $20 \%$ compared to the 1990 level.

The Directive 2009/28/EC [9] of the European Parliament and of the Council of 23 April 2009 on the promotion of the use of energy from renewable sources sets out the rules for how Poland is to achieve the $15 \%$ share of renewables in the total of primary energy generated in 2020. The National Action Plan voices concerns that the goals of this Directive may not be met. These fears are confirmed by the computation of renewable energy (RE) share in the national electricity consumption for the last several years. The share of RE was $5.7 \%$ in 2009 and rose to $8 \%$ in 2011.

\section{Hydropower engineering in Poland and Europe}

When analysing the development of hydropower engineering, one must differentiate between the so called Large and Small Hydro Plants (LHP and SHP respectively) [10-13]. The difference between those two lies in the installed capacity. In Europe the upper limit for a SHP installed capacity may vary: 1.5 MW in Luxemburg and Sweden, 5.0 MW in Poland [14], Austria, Greece, the Netherlands and Germany and $10 \mathrm{MW}$ in Belgium, Spain, Ireland and Portugal.

Water in Poland is scarce. The average annual rainfall is about $600 \mathrm{~mm}$. Our surface water resources are in short supply - on this criterion we are ranked $26^{\text {th }}$ in Europe. A statistical Pole has only about 1.8 thousand $\mathrm{m}^{3}$ of water available per year, three times less than an average European and ten times less than a typical US citizen. This modest surface water balance is improved by underground drinking water resources. The overall storage capacity of existing reservoirs is only $3 \mathrm{~km}^{3}$, which amounts to only $5 \%$ of water flowing to the sea. As of today, there are practically no new reservoirs being built in Poland.

SHPs are an important element of national economy and water management. Small hydropower plants [15-17]:

- $\quad$ provide cheap and clean electricity,

- play an important role in ecology and environmental protection,

- contribute to the control of water profiles,

- improve soil humidity and groundwater levels,

- create a system of reservoirs and maintain the right water levels through small retention,

- $\quad$ are useful for agriculture and for both city and country inhabitants: turbine trash screens eliminate floating debris and thus improve water quality through mechanical purification. Moreover, SHP plants oxygenate water and thereby improve its potential for biological self-purification,

- $\quad$ are beneficial for the electrical power grid by improving the LV and MV distribution network parameters. Electricity generated in SHPs is used by consumers in the closest vicinity of the plant. This eliminates energy loss due to transmission, distribution and transformation (large power plants may lose up to $25 \%$ of generated energy). 
SHPs are usually perfectly blended into landscape and are generally considered to be the most human-friendly renewable energy source.

According to the regulation of the Minister of Environment [18] of 20 April 2007 on the technical conditions to be met by hydro structures and their location, power plants in Poland are divided into four classes, depending on installed capacity:

- over $150 \mathrm{MW}$ - class I,

- 50-150 MW - class II,

- 5-50 MW - class III,

- below $5 \mathrm{MW}$ - class IV.

In Poland, SHPs are divided into three groups [19]:

- micro power plants, which generate up to $300 \mathrm{~kW}$ and are located mainly on existing barrages. As of today in Poland there are about 500 operating power plants of this type. Their share in the overall national production stands at approx. $0.6 \%$,

- mini power plants, with capacities ranging from 301 to $1000 \mathrm{~kW}$, equipped in automated control systems as well as systems allowing them to be integrated into the local grid. These facilities have their own transformer stations and are connected to the LV and MV networks. Transmission loss is low. Such facilities are of the run-of-theriver type and cause no water level variations above the barrage. In Poland there are more than 60 operating power plants of this type,

- small power plants, with capacities ranging from 1001 to $5000 \mathrm{~kW}$. These are the hydro engineering facilities which were not closed after 1945. Most of them belong to the state. As there are not many locations left in Poland where the installed capacity could be that high, little progress is to be expected in this group.

\section{Characteristics of the Nysa Klodzka River}

The Nysa Klodzka River is a left tributary of the Odra River, into which it flows at $\mathrm{km} 181.3$ in the Opolskie province (Fig. 1). The river's total length is $181.7 \mathrm{~km}$. Its catchment area stands at $4565.7 \mathrm{~km}^{2}$. The Nysa Klodzka River is a mountain river with an average gradient of $9.05 \%$. The river starts in the Dolnoslaskie province, through which it flows over a distance of $89.4 \mathrm{~km}$. The river supplies several reservoirs: the Topola, Kozielno, Otmuchow and Nysa, which are all part of a flood protection system. Its main tributaries in the Lower Silesia are: the Bystrzyca Klodzka, Biala Ladecka, Bystrzyca Dusznicka, Scinawka and Buszowka. Its catchment is varied and includes both large protected areas and highly urbanized areas with many tourist villages and resorts.

Due to the variable meteorological conditions, changeable both in time and in space, and because of the terrain orography, the hydrology of the Nysa Klodzka catchment is highly complicated. Flood waves formation depends on the local topographical conditions, river network system, geological makeup and human business activity. The distribution of average annual rainfall clearly displays the influence of hypsometry and topographic profile. The maximum average rainfall usually falls in July whereas the lowest average rainfall is received in winter, with February being usually the driest month in the year.

There are 9 water-level gauges on the Nysa Klodzka River, all of which are monitored by the Institute of Meteorology and Water Management (IMGW). 


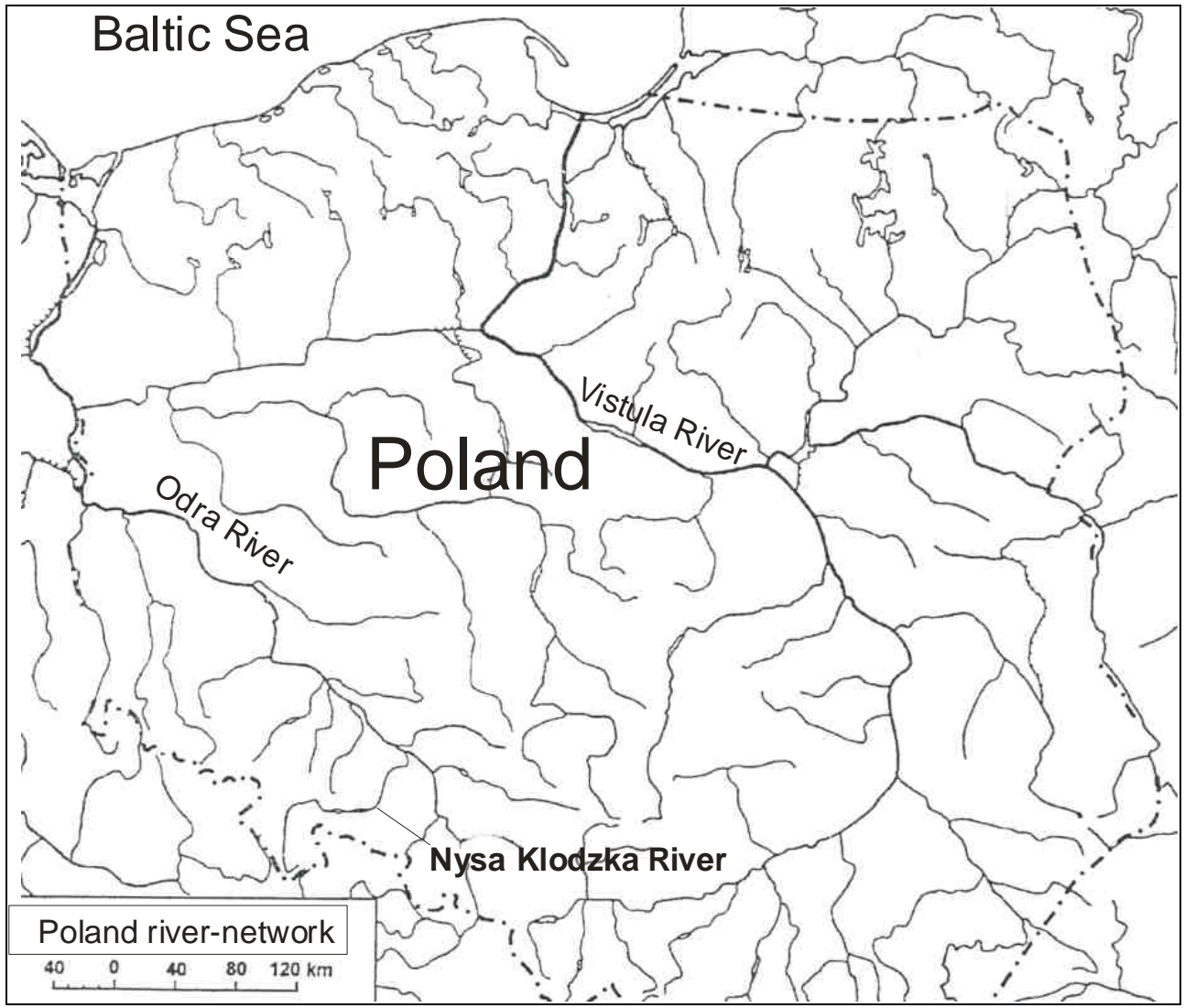

Fig. 1. Location of the Nysa Klodzka River in Poland

\section{Existing hydropower plants on the Nysa Klodzka River}

The Nysa Klodzka catchment area is currently witnessing intensive hydropower development. There are 24 hydroelectric power plants here (of either run-of-the-river ( $r$ ) or conventional/dam (c) type) with capacities of up to $5 \mathrm{MW}$ (Table 1). The highest capacities are installed at Otmuchow and Nysa-Glebinow (4.8 MW and 3.28 MW respectively), and the lowest capacities (of several kW each) are at Nowa Morawa on the Biala Ladecka, Klodzko on the Bystrzyca Dusznicka and Rynarcice on the Scinawka Niemodlinska. These power plants have several owners: the State, various companies such as Hydroelektrownie Dolnego Slaska sp. z o.o., TAURON Ekoenergia sp. z o.o., Hydroenergia Sp. z o.o. Gdansk, EnergoInvest Group sp. z o.o., MEW s.c. Klodzko as well as private investors. The overall capacity of all the existing hydropower plants on the Nysa Klodzka River is estimated at $17.6 \mathrm{MW}$. 
Existing hydropower plants in the Nysa Klodzka catchment

\begin{tabular}{|c|c|c|c|c|}
\hline No & Power plant name & River name & $\begin{array}{c}\text { River } \\
\text { km }\end{array}$ & $\begin{array}{c}\text { Power plant } \\
\text { capacity } \\
{[\mathrm{MW}]} \\
\end{array}$ \\
\hline 1 & Otmuchow(c) & Nysa Klodzka & 75.80 & 4.800 \\
\hline 2 & Nysa-Glebinow(c) & Nysa Klodzka & 64.00 & 3.280 \\
\hline 3 & Nysa(r) & Nysa Klodzka & 62.40 & 0.840 \\
\hline 4 & Opolnica(r) & Nysa Klodzka & 116.60 & 0.250 \\
\hline 5 & Lawica(r) & Nysa Klodzka & 128.50 & 0.110 \\
\hline 6 & Bystrzyca(r) & Nysa Klodzka & 150.30 & 0.260 \\
\hline 7 & Klodzko I(r) & Nysa Klodzka-Mlynowka & 136.24 & 0.045 \\
\hline 8 & Klodzko II(r) & Nysa Klodzka-Mlynowka & 105.00 & 0.035 \\
\hline 9 & Wiecmierzyce(r) & Nysa Klodzka & 36.48 & 1.890 \\
\hline 10 & Kozielno(r) & Nysa Klodzka & 93.40 & 1.900 \\
\hline 11 & Topola(r) & Nysa Klodzka & 97.70 & 1.500 \\
\hline 12 & Przylek(r) & Nysa Klodzka & 111.71 & 0.302 \\
\hline 13 & Michalow-Sarny Wielkie(r) & Nysa Klodzka & 21.40 & 0.600 \\
\hline 14 & Piatkowice $(\mathrm{r})$ & Nysa Klodzka & 49.14 & 0.945 \\
\hline 15 & Lewin Brzeski(r) & Nysa Klodzka & 13.66 & 0.1 \\
\hline 16 & Mlynow(r) & Nysa Klodzka & 125.37 & 0.1 \\
\hline 17 & Nowa Morawa(r) & Biala Ladecka & - & 0.002 \\
\hline 18 & Krosnowice(r) & Biala Ladecka & - & 0.140 \\
\hline 19 & Klodzko III(r) & Bystrzyca Dusznicka & - & 0.010 \\
\hline 20 & Piszkowice(r) & Scinawka & - & 0.040 \\
\hline 21 & Nowy Swietow(r) & Biala Glucholaska & - & 0.210 \\
\hline 22 & Rynarcice(r) & Scinawka Niemodlinska & - & 0.060 \\
\hline 23 & Glucholazy(r) & Biala Glucholaska & - & 0.150 \\
\hline 24 & Szydlowiec(r) & Scinawka Niemodlinska & - & 0,020 \\
\hline \multicolumn{5}{|c|}{ Total capacity - 17.589 MW } \\
\hline
\end{tabular}

\section{Locations for hydropower plants on the Nysa Klodzka River}

Field research works on the Nysa Klodzka River intended to locate the damming structures for possible SHPs were carried out between 2009 and 2011. All of the investigated structures were solid or moveable weirs, either operational or destroyed. It must be emphasised that the authors did not attempt to identify new locations, where no damming structure exists or used to exist. Such locations could be still found, despite the existing hydraulic structures being already scattered on the river quite densely. Our research proves that there are at least eight locations on the Nysa Klodzka River where SHPs could be built. All these places, listed in Table 2, are located between $\mathrm{km} 13.83$ and $\mathrm{km} 126$ of the river. The heads for proposed locations range from $1.7 \mathrm{~m}$ to $3.7 \mathrm{~m}$. Average flow rate varies from 15 to $38.2 \mathrm{~m}^{3} \mathrm{~s}^{-1}$. One of the eight locations selected for a possible SHP is shown in Figure 2. 


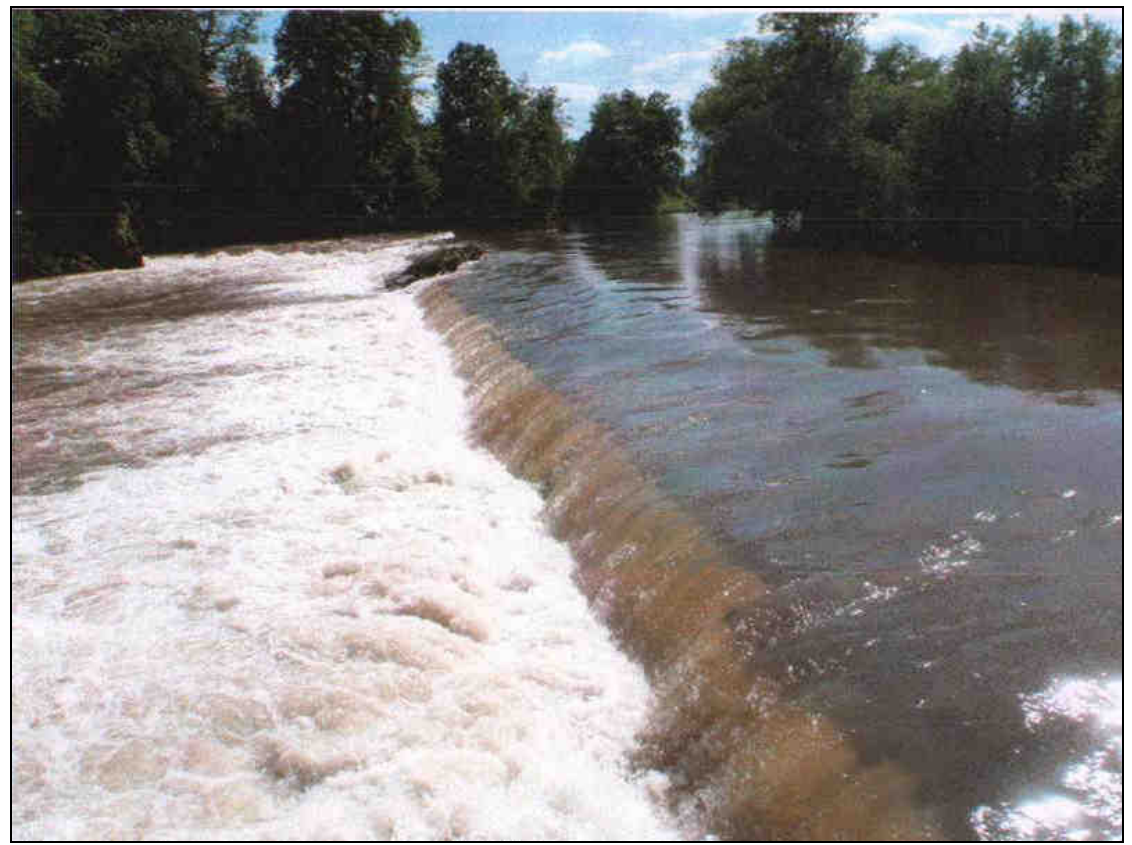

Fig. 2. One of the eight locations selected for a possible small hydropower plant: the Nysa Klodzka River at km 98.74

Table 2

Locations allowing construction of hydropower plants on the Nysa Klodzka River

\begin{tabular}{|c|c|c|}
\hline No & River [km] & Damming structure \\
\hline 1 & 13.83 & Destroyed stone weir \\
\hline 2 & 22.09 & Flap gate weir \\
\hline 3 & 49.14 & Concrete solid weir \\
\hline 4 & 61.37 & Concrete solid weir \\
\hline 5 & 63.86 & Gate weir \\
\hline 6 & 98.74 & Concrete solid weir \\
\hline 7 & 111.71 & Concrete solid weir \\
\hline 8 & 126.00 & Concrete solid weir \\
\hline
\end{tabular}

\section{Research and computational methods}

The theoretical power of the investigated watercourse $N_{a v}[\mathrm{~kW}]$ is given by [20]:

$$
N_{a v}=9.81 Q_{a v} H_{a v}
$$

where: $Q_{a v}$ - flow averaged over a long enough time (several years) $\left[\mathrm{m}^{3} \mathrm{~s}^{-1}\right], H_{a v}$ - head (height difference) over the river reach $[\mathrm{m}]$.

The theoretical average energy $E_{a v}[\mathrm{kWh}]$ obtained for the investigated river reach is given by:

$$
E_{a v}=8760 N_{a v}
$$


In order to determine the fundamental parameters for a run-of-the-river SHP, one must carry out the following steps:

- calculate the flow $Q$ of the river for a given computational cross-section and plot the curve of the total flow time in a year $T$,

- determine the upper water level $h_{u}$,

- determine the lower water level $h_{l}$ as a function of flow $Q$ (flow rate curve),

- $\quad$ estimate the heads $H$ and plot the curve of the total head time vs. flow $Q$,

- calculate the power plant capacity $N_{E t}[\mathrm{~kW}]$ for given $Q_{E t}$ values using the formula:

$$
N_{a v}=9.81 H_{t} Q_{E t} \sum \eta
$$

where: $\Sigma \eta$ - the product of efficiencies of individual components ie turbine $\eta_{t}$, gear $\eta_{g}$, generator and block transformer $\eta_{t r}$. These efficiency values are as follows: $\eta_{t}=0.88-0.93$; $\eta_{g}=0.95-0.98$ and $\eta_{t r}=0.97-0.995$. As a result, the product of all the above efficiencies is estimated at 0.84-0.90 [21-24];

- $\quad$ estimate the installed discharge $Q_{i}$ of the plant and in the case of a power plant with just one turbine - also the installed discharge of water turbine,

- $\quad$ estimate the total annual production $A_{E}[\mathrm{kWh}]$,

- $\quad$ based on the annual production value $A_{E}$ and the capacity $N_{i}$ calculate the so called usage time of the power plant installed capacity $T_{E}[\mathrm{~h}]$ according to the following formula:

$$
T_{E}=\frac{A_{E}}{N_{i}}
$$

The flow rate value required to calculate the capacity of a power plant can be determined based on the hydraulic measurements of the river (Hydrologic Yearbook of Surface Water and the Results of Hydraulic Measurements published by the IMGW) or based on the average unitary runoffs $[25,26]$.

When designing a run-of-the-river hydropower plant, the installed discharge $Q_{i}$, ie the rated flow rate through all the water turbines installed in the plant being designed, is usually assumed to be either $Q_{50 \%}$ or SSQ. In order to estimate the capacity and the annual output of a run-of-the-river plant, flow rate is assumed to be the flow averaged over several years (SSQ) and $Q_{i}$ is calculated in three variants:

I. $Q_{i}=(0.80-0.95)$ SSQ in which case $T_{E} \cong 6000 \mathrm{~h}$,

II. $Q_{i}=\mathrm{SSQ}$ in which case $T_{E} \cong 5500 \mathrm{~h}$,

III. $Q_{i}=(1.1-1.3) \mathrm{SSQ}$ in which case $T_{E} \cong 5000 \mathrm{~h}$,

The approximate annual power generation $A_{E}[\mathrm{kWh} /$ year $]$ is then calculated as:

$$
A_{E}=T_{E} N_{i}
$$

\section{Results and discussion}

The calculated values of average power and energy of a stream of flowing water for the proposed locations on the Nysa Klodzka River are given in Table 3. The theoretical power of a stream of water $N_{a v}$ varies from 250 to $1347 \mathrm{~kW}$ and its average energy $E_{a v}$ is estimated at 2.2-11.8 GWh/year. The total power $N$ and energy $E$ of the Nysa Klodzka River for all the proposed locations for SHP facilities amount to $6.25 \mathrm{MW}$ and 55.4 GWh/year respectively. 
Average power $N_{a v}$ and energy $E_{a v}$ for proposed locations for SHPs on the Nysa Klodzka River

\begin{tabular}{|c|c|c|c|}
\hline No & $\begin{array}{c}\text { River } \\
{[\mathbf{k m}]}\end{array}$ & $\begin{array}{c}\text { Power } \boldsymbol{N}_{\boldsymbol{a v}} \\
{[\mathbf{k W}]}\end{array}$ & $\begin{array}{c}\text { Energy } \boldsymbol{E}_{\boldsymbol{a v}} \\
{[\mathbf{G W h} / \mathbf{y e a r}]}\end{array}$ \\
\hline 1 & 13.83 & 674 & 5.9 \\
\hline 2 & 22.09 & 1139 & 10.0 \\
\hline 3 & 49.14 & 1347 & 11.8 \\
\hline 4 & 61.37 & 989 & 8.9 \\
\hline 5 & 63.86 & 718 & 6.5 \\
\hline 6 & 98.74 & 498 & 4.5 \\
\hline 7 & 111.71 & 635 & 5.6 \\
\hline 8 & 126.00 & 250 & 2.2 \\
\hline
\end{tabular}

Power generation in $\mathrm{kWh}$ and installed capacity in $\mathrm{kW}$ of run-of-the-river hydropower plants are estimated based on the available basic hydrological data. In order to determine the installed capacity $N_{i}(\mathrm{~kW})$ and expected energy production $A_{E}(\mathrm{GWh} /$ year) a $15 \%$ water loss and an average turbine efficiency of $80 \%$ have been assumed. The authors have carried out the following calculations:

- the amount of water flowing through a given river section over a one year period $S Q_{r}=S Q \times 31.536 \times 10^{6}\left[\mathrm{~m}^{3} /\right.$ year $]$,

- the maximum turbine flow rate $Q_{\max , t}=1.5 \times S Q\left[\mathrm{~m}^{3} \mathrm{~s}^{-1}\right]$,

- $\quad$ water loss $S_{w}=0.15 \times S Q_{r}\left[\mathrm{~m}^{3}\right]$,

- usable flow rate of water $Q_{u}=S Q_{r}-S_{w}\left[\mathrm{~m}^{3}\right]$.

Table 4 shows the numerical results for expected power generation and installed capacity, which are proportional to the investment required to build a power plant at each of these locations on the Nysa Klodzka River. The total installed capacity for all the proposed locations for new SHPs amounts to about $8 \mathrm{MW}$, ranging from $319 \mathrm{~kW}$ (km 126) to $1717 \mathrm{~kW}(\mathrm{~km} \mathrm{49})$. The annual power generation for all the eight locations is estimated at $37.5 \mathrm{GWh}$.

Table 4

Capacity and generation for proposed locations for SHPs on the Nysa Klodzka River

\begin{tabular}{|c|c|c|c|c|c|c|c|c|c|}
\hline No & $\begin{array}{c}\text { River } \\
\text { km }\end{array}$ & $\underset{\left[\mathrm{m}^{3} \mathbf{s}^{-1}\right]}{S Q}$ & $\begin{array}{c}\text { Head H } \\
{[\mathbf{m}]}\end{array}$ & $\begin{array}{c}S Q_{r}^{*} 10^{6} \\
{\left[\mathrm{~m}^{3} / \text { year] }\right.}\end{array}$ & $\begin{array}{c}Q_{\max . t} \\
{\left[\mathrm{~m}^{3} \mathbf{s}^{-1}\right]}\end{array}$ & $\begin{array}{c}S_{w} * 10^{6} \\
{\left[\mathrm{~m}^{3}\right]}\end{array}$ & $\begin{array}{c}Q_{u} * 10^{6} \\
{\left[\mathrm{~m}^{3}\right]}\end{array}$ & $\begin{array}{c}\boldsymbol{A}_{E} \\
\text { [GWh/year] }\end{array}$ & $\begin{array}{c}N_{i} \\
{[\mathrm{~kW}]}\end{array}$ \\
\hline 1 & 13.83 & 38.2 & 1.8 & 1204.7 & 57.3 & 180.7 & 1023.9 & 4.018 & 860 \\
\hline 2 & 22.09 & 37.1 & 3.1 & 1169.9 & 55.65 & 175.5 & 994.4 & 6.786 & 1452 \\
\hline 3 & 49.14 & 37.1 & 3.7 & 1169.9 & 55.65 & 175.5 & 994.4 & 8.022 & 1717 \\
\hline 4 & 61.37 & 31.5 & 3.2 & 993.4 & 47.25 & 149.0 & 844.4 & 6.007 & 1256 \\
\hline 5 & 63.86 & 30.8 & 2.4 & 971.3 & 46.2 & 145.7 & 825.6 & 4.378 & 915 \\
\hline 6 & 98.74 & 22.8 & 2.3 & 719.0 & 34.2 & 107.9 & 611.1 & 3.037 & 634 \\
\hline 7 & 111.71 & 18.5 & 3.5 & 583.4 & 27.75 & 87.5 & 495.9 & 3.784 & 810 \\
\hline 8 & 126.00 & 15.0 & 1.7 & 473.0 & 22.5 & 70.9 & 402.1 & 1.490 & 319 \\
\hline \multicolumn{8}{|c|}{ Total } & 37.522 & 7963 \\
\hline
\end{tabular}

\section{Conclusions}

The conducted research and analysis of the Nysa Klodzka catchment prove that there are at least eight locations with existing damming structures in which small hydropower plants could be built. Calculated capacity and annual generation show that the plants would provide approximately $8 \mathrm{MW}$ and $37.5 \mathrm{GWh}$ respectively. Both the existing power plants 
and the newly proposed ones classify as SHPs. A comparison of all the existing and proposed SHPs shows that the new locations on the Nysa Klodzka River would increase the overall capacity by almost $50 \%$. In our opinion the construction of new hydropower plants in the Nysa Klodzka catchment would help to increase the share of hydropower in the total primary energy, which in view of the restrictive requirements and targets set by the EU for 2020 is well worth considering.

\section{References}

[1] Hydropower and Dams World Atlas and Industry Guide. Aqua-Media International. Sutton; 2004.

[2] ASCE, Committee on Hydropower Intakes. Guidelines for the Design of Intakes for Hydroelectric plants; 1995.

[3] The International Journal on Hydropower \& Dams: World Atlas \& Industry Guide; 2008.

[4] Cao Y, Pawłowski L. Ecol Chem Eng S. 2014;20(4):799-804. DOI: 10.2478/ECES-2013-0055.

[5] Water Framework Directive 2000/60/EC.

[6] Polish Water Law, DzU 2005.

[7] Kasperek R, Mokwa M, Wiatkowski M. Arch Environ Prot. 2013;39(2):29-43. DOI: 10.2478/aep-20130017.

[8] Bartle A., Hallowes G. Hydroelectric power: present role and future prospects. Proc of the Inst of Civil Eng. 2005;158:28-31.

[9] Directive 2009/28/EC of the European Parliament and of the Council of 23 April 2009 on the promotion of the use of energy from renewable sources and amending and subsequently repealing Directives 2001/77/EC and 2003/30/EC.

[10] Frosio N. Civil works degradation: a natural evolution or an original sin? Hidroenergia 2010; Paper 6A.05; Lozanna; 2010.

[11] Novak P, Moffat AIB, Nalluri C, Narayanan R. Hydraulic Structures. London and New York: Taylor \& Francis; 2001.

[12] Punys P, Söderberg C, Söderlund T, Wänn A. Strategic study for development of small hydropower in the European Union. ESHA/LHA/SERO; 2008.

[13] Radecki-Pawlik A. Fish passes as an environmental internal part of a hydraulic structure - investigations of a proposed optimal fish pass pool shape. Acta Hortic Reg. 2003;6:151-153.

[14] Polish Energy Law, DzU 2012, poz. 1059.

[15] Gulliver JS, Arndt REA. Hydropower Engineering Handbook. New York: McGraw Hill; 1991.

[16] Hayes D. Small plants. Int. Water Power and Dam Construction. 2004;12-13.

[17] Laks I, Kałuża T, Sojka M, Walczak Z, Wróżyński R. Problems with modelling water distribution in open channels with hydraulic engineering structures. Rocz Ochr Środow. (Annu Set The Environ Prot.). 2013;15(1):245-257.

[18] Polish Order of the Environment Minister, DzU 2007, poz. 579.

[19] Wiatkowski M, Kasperek R. Proc ECOpole. 2012;6(2):553-558. DOI: 10.2429/proc.2012.6(2)075.

[20] European Small Hydropower Association. Guide on How to Develop a Small Hydropower Plant; 2004.

[21] Jaeger C. Fluid Transients in Hydro-Electric Engineering Practice. Glasgow; 1977.

[22] Mosonyi E. Water Power Development. Budapest: Hungarian Academy of Sciences; 1987.

[23] Popescu M, Arsenic D, Vlase P. Applied Hydraulic Transients for Hydropower Plants and Pumping Stations. Rotterdam: Balkema; 2003.

[24] Raabe J. Hydropower. The design, use and function of hydromechanical, hydraulic and electrical equipment. VDI Verlag; 1985.

[25] Ravn J. Planning and implementation of hydropower projects. Hydropower Development Book Series: Trondheim: Norwegian Institute of Technology; 1992;5.

[26] Banasik K, Hejduk L. Flow duration curves for two small catchments with various records in lowland part of poland. Rocz Ochr Środow. (Annu Set The Environ Prot.). 2013;15(1):287-300. 


\title{
HYDROENERGETYCZNE WYKORZYSTANIE RZEKI NYSA KŁODZKA
}

\author{
${ }^{1}$ Instytut Inżynierii Środowiska, Wydział Inżynierii Kształtowania Środowiska i Geodezji, Uniwersytet \\ Przyrodniczy we Wrocławiu \\ ${ }^{2}$ Katedra Ochrony Powierzchni Ziemi, Wydział Przyrodniczo-Techniczny, Uniwersytet Opolski
}

\begin{abstract}
Abstrakt: Dyrektywa Parlamentu Europejskiego i Rady z 2009 r. w sprawie promowania stosowania energii ze źródeł odnawialnych określa zasady dojścia przez Polskę w 2020 r. do 15\% udziału tej energii w całej energii pierwotnej. Istnieją jednak obawy, czy uda się zrealizować cele zawarte w omawianej dyrektywie. Udział energii elektrycznej odnawialnej w krajowym zużyciu energii (150 TWh) wynosił: 8,6 TWh w 2009 roku $(5,7 \%)$ oraz 12 TWh w 2011 roku (8\%). Polska do roku 2005 miała mieć udział energii około 7,2\%. Z analizy mocy technologii OZE w Polsce wynika, że elektrownie wodne są na drugim miejscu (wg kryterium zainstalowanej mocy), jest ich 750 (moc prawie 0,95 GW), na pierwszym miejscu są wiatraki - moc 2 GW. Autorzy przebadali rzekę Nysę Kłodzką pod kątem budowy elektrowni wodnych i stwierdzili, że istnieje na niej osiem lokalizacji, gdzie można by zbudować elektrownie o mocach zainstalowanych od 319 do $1717 \mathrm{~kW}$. Sumaryczna (roczna) oczekiwana produkcja energii dla ww. lokalizacji wyniosłaby ok. 37,5 GWh.
\end{abstract}

Słowa kluczowe: rzeka, odnawialne źródła energii, hydroenergetyka, produkcja energii 